\title{
Isolation of oligosaccharides from a partial-acid hydrolysate of pneumococcal type 3 polysaccharide for use in conjugate vaccines
}

\author{
Dirk J. Lefeber, ${ }^{\text {a }}$ Ricardo Gutiérrez Gallego, ${ }^{a}$ Christian H. Grün, ${ }^{\text {a }}$ Daniela Proietti, ${ }^{b}$ \\ Sandro D'Ascenzi, ${ }^{\mathrm{b}}$ Paolo Costantino, ${ }^{\mathrm{b}}$ Johannis P. Kamerling, ${ }^{\mathrm{a}, *}$ \\ Johannes F.G. Vliegenthart ${ }^{\mathrm{a}}$ \\ ${ }^{a}$ Department of Bio-Organic Chemistry, Bijvoet Center, Utrecht University, PO Box 80.075, NL-3508 TB Utrecht, The Netherlands \\ ${ }^{\mathrm{b}}$ Chiron Vaccines SpA, Via Fiorentina 1, I-53100 Siena, Italy
}

Received 17 December 2001; accepted 4 February 2002

\begin{abstract}
A series of well-defined oligosaccharide fragments of the capsular polysaccharide of Streptococcus pneumoniae type 3 has been generated. Partial-acid hydrolysis of the capsular polysaccharide, followed by fractionation of the oligosaccharide mixture by Sepharose Q ion-exchange chromatography yielded fragments containing one to seven $[\rightarrow 3)-\beta$-D-Glc $p$ A- $(1 \rightarrow 4)-\beta$-D-Glc $p$ - $(1 \rightarrow]$ repeating units. The isolated fragments were analysed for purity by high-pH anion-exchange chromatography with pulsed amperometric detection (HPAEC-PAD) using an IonPac AS11 column, and their structures were verified by ${ }^{1} \mathrm{H}$ NMR spectroscopy and nano-electrospray mass spectrometry. The oligosaccharides can be used to produce neoglycoprotein vaccines with a defined carbohydrate part. (c) 2002 Elsevier Science Ltd. All rights reserved.
\end{abstract}

Keywords: Streptococcus pneumoniae; Polysaccharide degradation; Conjugate vaccines; HPAEC-PAD

\section{Introduction}

The Gram-positive pathogenic bacterium Streptococcus pneumoniae causes diseases like otitis media, pneumonia and meningitis. Particularly young children, the elderly and immunocompromised patients are at high risk towards pneumococcal infections. Protection against pneumococci is conferred by antibodies against the polysaccharide capsule surrounding the bacterium. Carbohydrate material derived from this capsule is used in neoglycoprotein vaccines that induce a serotype-specific antibody response against the polysaccharide. Currently, vaccines exist against Haemophilus influenzae type $\mathrm{b},{ }^{1}$ Neisseria meningitidis serogroup $\mathrm{C},{ }^{2}$ and $S$. pneumoniae serotypes. ${ }^{3}$ These neoglycoproteins are prepared by conjugation of isolated capsular polysaccharides or a mixture of polysaccharide-derived oligosac-

\footnotetext{
* Corresponding author. Tel.: + 31-30-2533479; fax: + 3130-2540980.

E-mail address: kame@boc.chem.uu.nl (J.P. Kamerling).
}

charides to a protein carrier. The polysaccharideprotein conjugates have complex structures, whereas the oligosaccharide-protein conjugates contain mixtures of carbohydrate with respect to chain length and presented epitope. Especially in the case of a pneumococcal conjugate vaccine, wherein many serotypes have to be included, the presence of mixtures complicates the analysis of the conjugates. Such analyses are becoming increasingly important for product control. Therefore, more sophisticated methods for the isolation of fragments and for screening of their purity need to be developed. ${ }^{4,5}$ Especially, methods like NMR spectroscopy and mass spectrometry, ${ }^{6}$ combined with chromatographic techniques like HPAEC-PAD ${ }^{7}$ are suitable for characterising carbohydrate material used in conjugate vaccines. ${ }^{8}$

The capsular polysaccharide (CPS) of $S$. pneumoniae type 3 consists of $[\rightarrow 3)-\beta$-D-Glc $p$ A- $(1 \rightarrow 4)-\beta$-D-Glc $p$ $\left(1 \rightarrow\right.$ ] repeating units. ${ }^{9}, 10$ Partial-acid hydrolysis of the polysaccharide has been described before ${ }^{11-13}$ yielding fragments of increasing degree of oligomerisation with glucuronic acid at the nonreducing end, i.e., epitope A 
(Fig. 1). Enzymatic digestion of the polysaccharide using an enzyme from Bacillus palustris ${ }^{11,12,14-16}$ generates fragments of increasing chain lengths having the alternative epitope B (Fig. 1). Chemical synthesis has been performed to obtain short defined fragments. ${ }^{17-21}$ Oligosaccharides have been conjugated to a carrier protein as mixtures of different chain lengths via their reducing end ${ }^{22}$ or via multiple point attachment, ${ }^{23}$ forming lattice type structures. A more chemically defined conjugate consisted of a hexasaccharide coupled to a protein via reductive amination. ${ }^{24}$

In this report, the isolation and characterisation of a series of oligosaccharide fragments are reported, containing one to seven repeating units from the CPS of $S$. pneumoniae type 3 .

\section{Experimental}

Reagents. - Capsular polysaccharide (CPS) of $S$. pneumoniae type 3 (Pn 3) was obtained from Chiron Vaccines (Siena, Italy). $\mathrm{CF}_{3} \mathrm{COOH}$ and $\mathrm{H}_{2} \mathrm{SO}_{4}$ (concd) were purchased from E. Merck, and phenol from Fluka. All chemicals were of the highest purity commercially available.

Partial-acid hydrolysis. - To a solution of Pn 3 CPS $(50 \mathrm{mg})$ in bidistilled water $(25 \mathrm{~mL})$ was added $0.6 \mathrm{M}$ $\mathrm{CF}_{3} \mathrm{COOH}(25 \mathrm{~mL})$, and the mixture was heated for 3 $\mathrm{h}$ at $100^{\circ} \mathrm{C}$, then lyophilised. Lyophilisation from bidistilled water was repeated three times.

FPLC ion-exchange chromatography using Mono $Q$ or Sepharose Q. - The oligosaccharide mixtures were fractionated by ion-exchange chromatography on a Pharmacia Biotech FPLC system equipped with a 500 $\mu \mathrm{L}$ or $10 \mathrm{~mL}$ sample loop. Before use, solvents were filtered over a $0.22 \mu \mathrm{m}$ filter and degassed by flushing with helium. Samples were dissolved in bidistilled water and injected on the column through a $0.22 \mu \mathrm{m}$ filter.

Analytical scale fractionation of the oligosaccharide mixture $(1 \mathrm{mg} / \mathrm{mL})$ was performed by injection of $2 \mathrm{~mL}$ on a prepacked $1 \mathrm{~mL}$ gelbed Mono $\mathrm{Q}^{\circledR} \mathrm{HR} 5 / 5$ column (Pharmacia). Fractions were eluted with a flow rate of $0.5 \mathrm{~mL} / \mathrm{min}$, by isocratic elution with water for $4 \mathrm{~mL}$, followed by a gradient of $0-500 \mathrm{mM} \mathrm{NaCl}$ from $4-84$

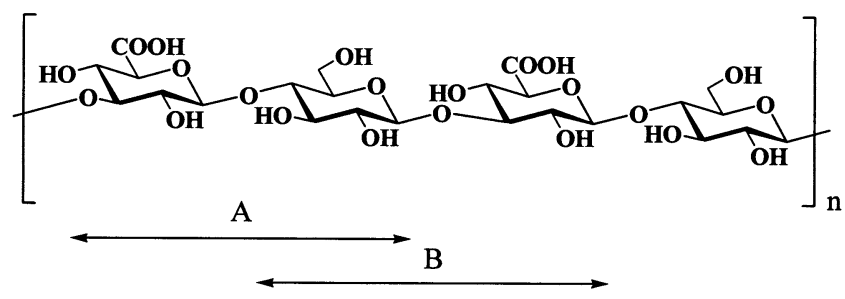

Fig. 1. Two repeating units of the CPS of S. pneumoniae type 3. Epitope A of increasing oligomerisation can be obtained by partial-acid hydrolysis, and epitope B of increasing oligomerisation by depolymerisation with an enzyme from $B$. palustris.
$\mathrm{mL}$. Fractions of $0.5 \mathrm{~mL}$ were collected and analysed for carbohydrate content by a phenol- $\mathrm{H}_{2} \mathrm{SO}_{4}$ assay. ${ }^{25}$

Preparative scale fractionation of the oligosaccharide mixture $(5.0 \mathrm{mg} / \mathrm{mL})$ was performed by injection of 10 $\mathrm{mL}$ on a $20 \mathrm{~mL}$ gelbed Sepharose $\mathrm{Q}^{\circledR}$ HR 16/10 column (Pharmacia). Fractions were eluted with a flow rate of $5.0 \mathrm{~mL} / \mathrm{min}$, by isocratic elution with water for $80 \mathrm{~mL}$, followed by a gradient of $0-213 \mathrm{mM} \mathrm{NaCl}$ from 80 to $750 \mathrm{~mL}$. Fractions of $5.0 \mathrm{~mL}$ were collected and analysed for carbohydrate content by a phenol- $\mathrm{H}_{2} \mathrm{SO}_{4}$ assay. Fractions containing pure oligosaccharides as observed by HPAEC-PAD and fractions containing a side-product (vide infra) were collected separately, lyophilised, redissolved in water, and desalted by Toyopearl ${ }^{\circledR}$ HW-40S (TosoHaas) size-exclusion chromatography in $5 \mathrm{mM} \mathrm{NH} \mathrm{NHAc}_{4} \mathrm{O}$

High-pH anion-exchange chromatography with pulsed amperometric detection (HPAEC-PAD).- The oligosaccharide mixture, fractions from ion-exchange chromatography, and the pooled fractions were analysed by injection with an AS 3500 autosampler on a Dionex DX-500 chromatographic system fitted with a GP40 gradient pump and an ED40 electrochemical detector (PAD detection) with a working gold electrode. Detection was performed using the following pulse potentials and durations: $E_{1}=0.1 \mathrm{~V}(400 \mathrm{~ms})$; $E_{2}=-0.2 \mathrm{~V}(20 \mathrm{~ms}) ; E_{3}=0.6 \mathrm{~V}(10 \mathrm{~ms}) ; E_{4}=-0.1 \mathrm{~V}$ (60 ms). Integration occurred from 200 to $400 \mathrm{~ms}$ during $E_{1}$ application. The system was equipped with a CarboPac ${ }^{\mathrm{TM}}$ PA10 or an IonPac ${ }^{\mathrm{TM}}$ AS11 column $(4 \times$ $250 \mathrm{~mm}$ ) in combination with a CarboPac ${ }^{\mathrm{TM}}$ PA10 or an IonPac ${ }^{\mathrm{TM}}$ AS11 guard column, respectively, and operated at rt. The eluent was degassed with helium and pressurised continuously with the eluent degas module of Dionex. Samples injected on a PA10 column were run with $100 \mathrm{mM} \mathrm{NaOH}$ at a flow rate of 1.0 $\mathrm{mL} / \mathrm{min}$ and a gradient of $\mathrm{NaOAc}$ from 0 to $700 \mathrm{mM}$ in $10.5 \mathrm{~min}$, from 700 to $800 \mathrm{mM}$ in $9.5 \mathrm{~min}$, and isocratically at $800 \mathrm{mM}$ for $10 \mathrm{~min}$. Samples injected on an AS11 column were run in $10 \mathrm{mM} \mathrm{NaOH}$ at a flow rate of $1.0 \mathrm{~mL} / \mathrm{min}$ with a gradient of $10-100 \mathrm{mM} \mathrm{NaOH}$ in $54 \mathrm{~min}$.

${ }^{1} H$ NMR spectroscopy. - Prior to analysis, oligosaccharide samples were dissolved in ${ }^{2} \mathrm{H}_{2} \mathrm{O}$ (99.9 atom\% ${ }^{2} \mathrm{H}$ ) to a concentration of $5 \mathrm{mg} / \mathrm{mL}$. The polysaccharide sample was dissolved in ${ }^{2} \mathrm{H}_{2} \mathrm{O}\left(99.9\right.$ atom $\left.\%{ }^{2} \mathrm{H}\right)$ containing $100 \mathrm{mM} \mathrm{NaCl}$ to a concentration of $0.5 \mathrm{mg} / \mathrm{mL}$. Resolution-enhanced 1D ${ }^{1} \mathrm{H}$ NMR spectra were recorded on a Bruker AMX-500 spectrometer at probe temperatures of 278,300 or $353 \mathrm{~K}$. Chemical shifts $(\delta)$ are expressed in ppm relative to internal acetone $(\delta$ 2.225).

Nano-electrospray mass spectrometry.-Electrospray ionisation (ESI) mass spectrometric analyses were performed on a Thermoquest/Finnigan LC-Q ion trap mass spectrometer equipped with a Protana nanoES 

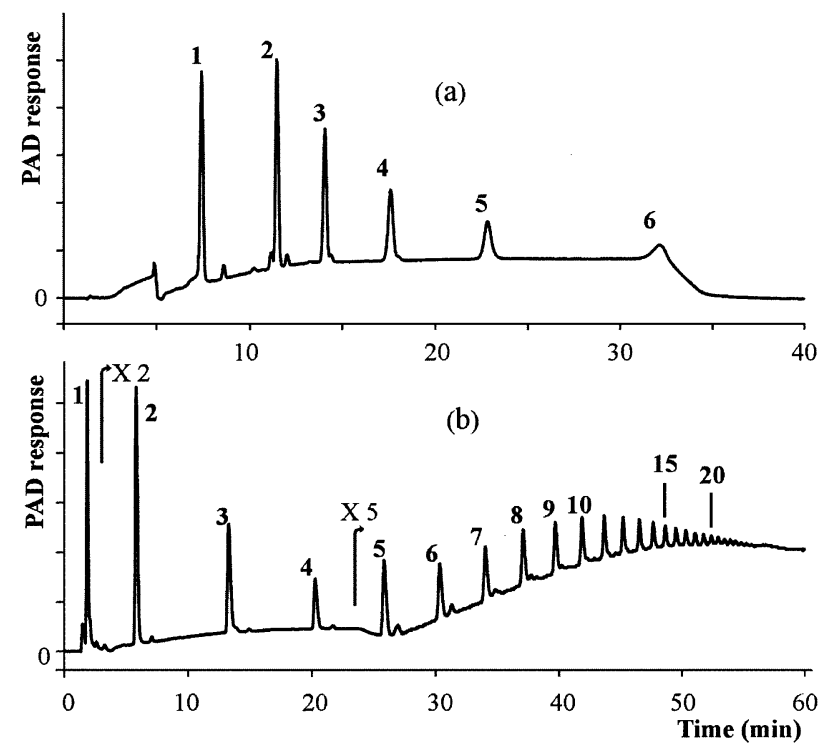

Fig. 2. HPAEC-PAD profiles of the oligosaccharide mixture obtained by partial-acid hydrolysis $\left(0.3 \mathrm{M} \mathrm{CF}_{3} \mathrm{COOH}, 3 \mathrm{~h}\right.$, $100{ }^{\circ} \mathrm{C}$ ) of Pn 3 CPS using (a) CarboPac PA10 or (b) IonPac AS11. Numbers indicate the size of the oligosaccharide fragments expressed in repeating units.
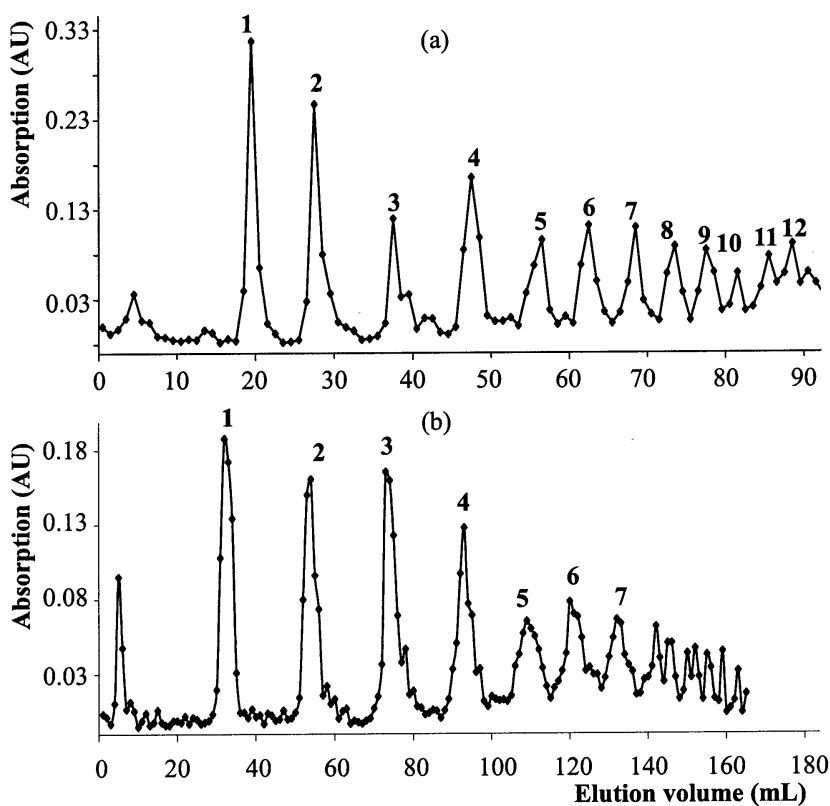

Fig. 3. Ion-exchange chromatograms of the oligosaccharide mixture obtained by partial-acid hydrolysis of Pn 3 CPS on (a) Mono Q and (b) Sepharose Q. Numbers correspond to the size of the oligosaccharide fragments expressed in repeating units.

sample probe. Samples in 1:1 $\mathrm{MeOH}$-water with an approximate concentration of $10-30 \mathrm{pmol} / \mu \mathrm{L}$ were prepared as follows. From a solution of the oligosaccharide in bidistilled water $(2 \mu \mathrm{g} / \mu \mathrm{L}), 5 \mu \mathrm{L}$ aliquots were diluted to $500 \mu \mathrm{L}$ with 1:1 $\mathrm{MeOH}$-water. For each experiment, $2 \mu \mathrm{L}$ were loaded into the capillary. The capillary temperature was set to $180^{\circ} \mathrm{C}$. Spectra were taken in the negative-ion mode with a cone voltage of $1.5 \mathrm{kV}$ and a capillary voltage of $-46.0 \mathrm{~V}$.

\section{Results and discussion}

Partial-acid hydrolysis and fractionation of the oligosaccharide mixture by ion-exchange chromatography. - The partial-acid hydrolysis of Pn 3 CPS with 0.3 $\mathrm{M} \mathrm{CF}{ }_{3} \mathrm{COOH}$ was followed in time. The composition of the oligosaccharide mixture after $3 \mathrm{~h}$ of hydrolysis as analysed by HPAEC-PAD is shown in Fig. 2. Using a CarboPac PA10 column, a high salt gradient was needed for the elution of fragments up to six repeating units (Fig. 2(a)). Better results were obtained when using an IonPac AS11 column (Fig. 2(b)). Fragments of over 20 repeating units were shown as isolated peaks. Small additional peaks for fragments of 1-9 repeating units indicated the presence of side-products (vide infra).

In Fig. 3(a), the fractionation of the oligosaccharide mixture by ion-exchange chromatography on analytical scale with a Mono Q HR 5/5 ion-exchange column is shown. The composition of the individual fractions of a peak was analysed by HPAEC-PAD on IonPac AS11. The side-products as mentioned above were shown to reside in the faster eluting fractions of a Mono Q peak. A similar fractionation pattern of the oligosaccharide mixture as observed for Mono $Q$ was obtained on a preparative scale using a Sepharose Q HR 16/10 ion-exchange column (Fig. 3(b)). Fractions belonging to one peak were collected thereby omitting the fractions contaminated with side-product, which were collected separately. Starting with $250 \mathrm{mg}$ of polysaccharide, 12-18 $\mathrm{mg}$ of each oligosaccharide fragment $(n=1-7)$ was obtained.

Purity analysis of the isolated fragments from Sepharose $Q$ by HPAEC-PAD on IonPac AS11.-The purity of the pooled fractions was analysed by HPAECPAD. In Fig. 4, the IonPac AS11 profiles are shown of the pure and of the side-product-containing fractions.

Characterisation of the oligosaccharides by ${ }^{1} \mathrm{H} N M R$ spectroscopy and nano-electrospray mass spectrometry. - ${ }^{1} \mathrm{H}$ NMR spectroscopy and nano-electrospray mass spectrometry were used for the characterisation of the oligosaccharides. The $1 \mathrm{D}{ }^{1} \mathrm{H}$ NMR spectra of the oligosaccharides having a glucuronic acid residue at the non-reducing end and a glucose residue at the reducing end (e.g., tetradecasaccharide, Fig. 5(a)) and the polysaccharide (Fig. 5(b)) were in good agreement. Due to the high viscosity of the polysaccharide, proton signals were only resolved upon addition of sodium chloride $(100 \mathrm{mM})$ and at a probe temperature of $353 \mathrm{~K}$. 


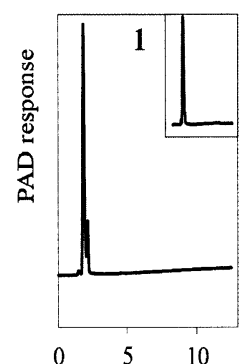

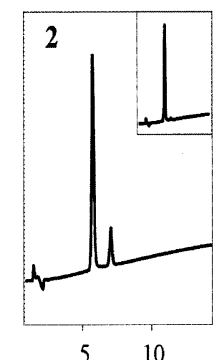

10

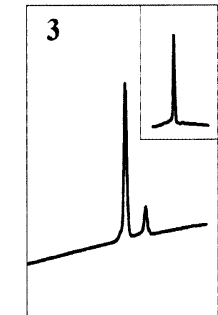

$10 \quad 15$ Time (min)

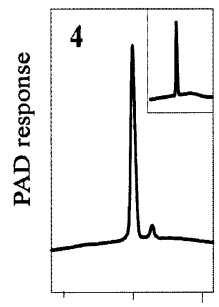

$15 \quad 20 \quad 25$

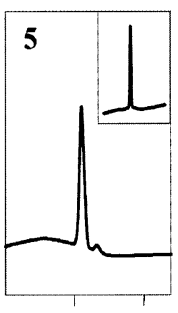

2530

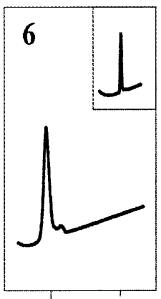

$30 \quad 35$

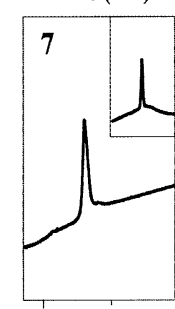

$30 \quad 35$
Fig. 4. HPAEC-PAD profiles of pooled side-product containing Sepharose Q fractions on IonPac AS11. Pooled fractions containing pure products are shown as inserts, $2.5 \times$ reduced in size. Numbers correspond to the size of the oligosaccharide fragments expressed in repeating units.

In Fig. 6, the anomeric regions of the $1 \mathrm{D}{ }^{1} \mathrm{H}$ NMR spectra of the $(\mathrm{GlcA}-\mathrm{Glc})_{n}$ oligosaccharides $(n=1-7)$ are shown. The positions of the anomeric signals were in good agreement with literature data of comparable synthetic saccharides, ${ }^{19}$ and their chemical shifts are reported in Table 1. Nano-electrospray mass spectrometry confirmed the molecular masses of the oligosaccharide fragments. In Table 2, their molecular masses are reported.
In Fig. 7, the structures of the possible side-products (vide supra) resulting from partial-acid hydrolysis of Pn 3 CPS are shown. The fractions containing as major product the fragments of 1 and 2 repeating units, contaminated with side-product as observed by HPAEC-PAD, were characterised by $1 \mathrm{D}{ }^{1} \mathrm{H}$ NMR spectroscopy (Fig. 8(a) and (b), respectively). With respect to the side-product, the signals at $4.803 \mathrm{ppm}$ (Fig. 8(a)) and 4.805 ppm (Fig. 8(b)) represent glucose at the nonreducing end, the signal at $4.534 \mathrm{ppm}$ (Fig. 8(a)) stems from internal glucuronic acid. This indicates the presence of Glc-GlcA-Glc and Glc-GlcA-GlcGlcA-Glc sequences (structures I, Fig. 7). These sideproducts originate from cleavage of the $\beta$-D-Glc $p$ A- $(1 \rightarrow 4)-\beta$-D-Glc $p$ linkage. In the mass spectrum of the side-product-containing fraction $(n=2$, Fig. 9(a)), besides the ion at $m / z 693.5$ an additional ion at $m / z 855.3$ is shown. This corresponds to the molecular ion $\left([\mathrm{M}-\mathrm{H}]^{-}\right)$of $\mathrm{GlcA}_{2} \mathrm{Glc}_{3}$, which confirms the identity of the side-products having a glucose residue at the nonreducing end (Fig. 7; structure I).

Careful inspection of the 1D ${ }^{1} \mathrm{H}$ NMR spectrum of the pure tetrasaccharide shows a minor additional signal at $5.231 \mathrm{ppm}$ (Fig. 8(c)), indicating the $\alpha$-anomeric proton of glucuronic acid, and thus, the presence of a GlcA-Glc-GlcA sequence with structure II (Fig. 7). In the mass spectrum of the pure tetrasaccharide (Fig. 9(b)) an ion of low abundance is observed at $\mathrm{m} / z$ 531.1, corresponding to the molecular ion $\left([\mathrm{M}-\mathrm{H}]^{-}\right)$of $\mathrm{GlcA}_{2}$ Glc. This confirms the molecular mass and structure of the trisaccharide.

The amounts of the two side-products co-eluting with the tetrasaccharide fragment, i.e., Glc-GlcA-Glc-

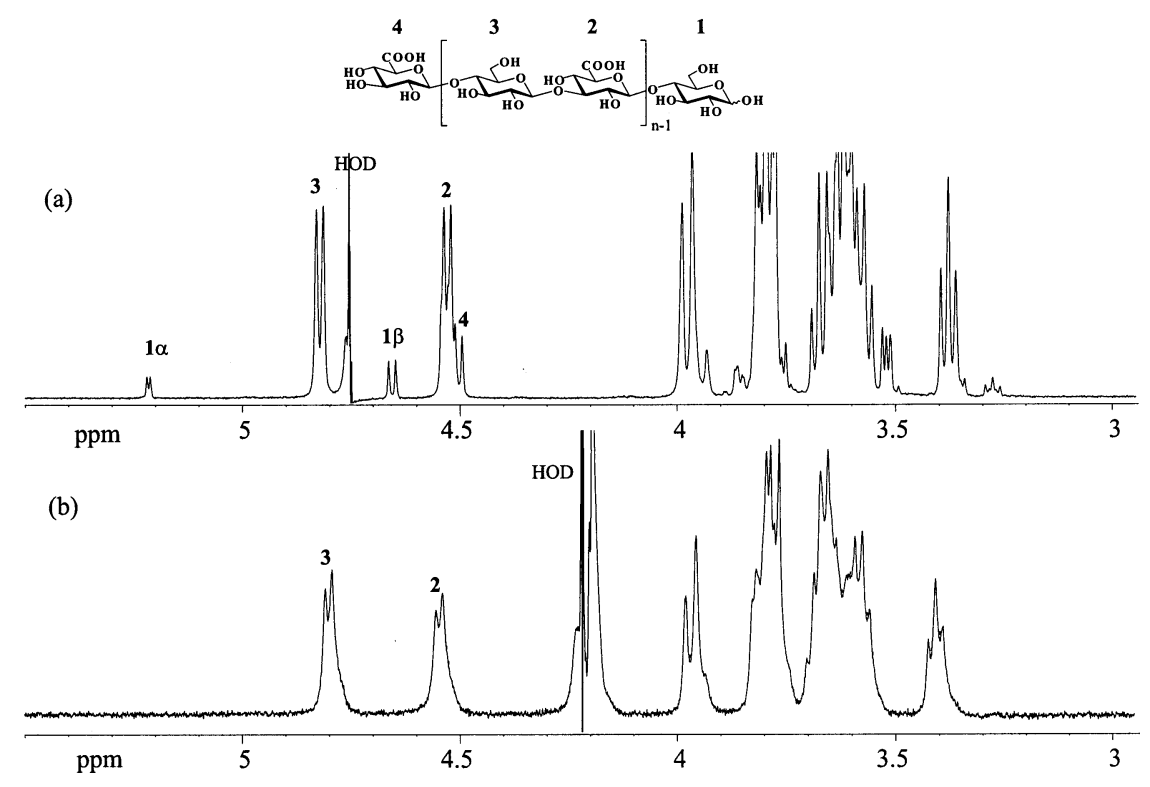

Fig. 5. $500 \mathrm{MHz}{ }^{1} \mathrm{H}$ NMR spectra of (a) the tetradecasaccharide fragment at $300 \mathrm{~K}$ and (b) the native polysaccharide at $353 \mathrm{~K}$. The anomeric protons are indicated. 

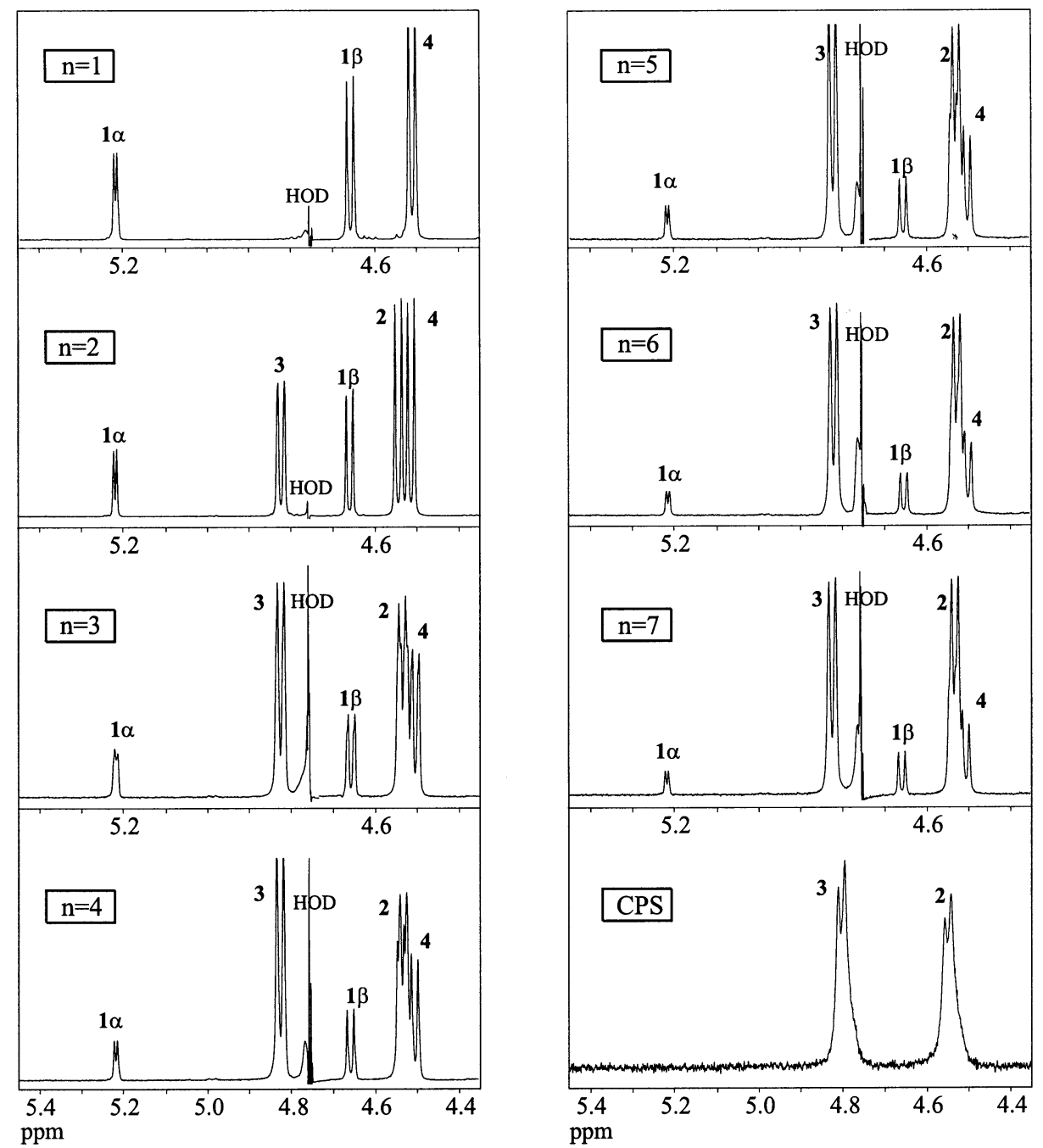

Fig. 6. Anomeric regions of the ${ }^{1} \mathrm{H}$ NMR spectra at $300 \mathrm{~K}$ of the di- to tetradecasaccharide fragments $(n=1-7)$ and the capsular polysaccharide $(353 \mathrm{~K})$. Numbers refer to the structure in Fig. 5.

Table 1

${ }^{1} \mathrm{H}$ NMR chemical shifts of the anomeric protons of the $(\mathrm{GlcA}-\mathrm{Glc})_{n}$ oligosaccharide fragments $(n=1-7)$ at $300 \mathrm{~K}$ and of the CPS at $353 \mathrm{~K}$

\begin{tabular}{|c|c|c|c|c|c|c|c|c|}
\hline & $n=1^{\mathrm{a}}$ & $n=2$ & $n=3$ & $n=4$ & $n=5$ & $n=6$ & $n=7$ & CPS \\
\hline $1^{b} \alpha$ & $\begin{array}{l}5.218 \\
(3.7)\end{array}$ & $\begin{array}{l}5.217 \\
(3.7)\end{array}$ & $\begin{array}{l}5.217 \\
(3.7)\end{array}$ & $\begin{array}{l}5.217 \\
(3.7)\end{array}$ & $\begin{array}{l}5.216 \\
(3.7)\end{array}$ & $\begin{array}{l}5.216 \\
(3.7)\end{array}$ & $\begin{array}{l}5.216 \\
(3.7)\end{array}$ & \\
\hline $1 \beta$ & $\begin{array}{l}4.659 \\
(8.2)\end{array}$ & $\begin{array}{l}4.657 \\
(7.9)\end{array}$ & $\begin{array}{l}4.657 \\
(7.9)\end{array}$ & $\begin{array}{l}4.658 \\
(7.9)\end{array}$ & $\begin{array}{l}4.657 \\
(8.0)\end{array}$ & $\begin{array}{l}4.656 \\
(8.3)\end{array}$ & $\begin{array}{l}4.657 \\
(7.9)\end{array}$ & \\
\hline 3 & & $\begin{array}{l}4.820 \\
(8.0)\end{array}$ & $\begin{array}{l}4.825 \\
(8.0)\end{array}$ & $\begin{array}{l}4.826 \\
(7.9)\end{array}$ & $\begin{array}{l}4.823 \\
(8.0)\end{array}$ & $\begin{array}{l}4.824 \\
(8.0)\end{array}$ & $\begin{array}{l}4.822 \\
(8.0)\end{array}$ & $\begin{array}{l}4.803 \\
(7.6)\end{array}$ \\
\hline 4 & $\begin{array}{l}4.512 \\
(8.0)\end{array}$ & $\begin{array}{l}4.510 \\
(8.0)\end{array}$ & $\begin{array}{l}4.503 \\
(8.0)\end{array}$ & $\begin{array}{l}4.505 \\
(8.0)\end{array}$ & $\begin{array}{l}4.503 \\
(7.9)\end{array}$ & $\begin{array}{l}4.503 \\
(8.0)\end{array}$ & $\begin{array}{l}4.504 \\
(7.9)\end{array}$ & \\
\hline 2 & & $\begin{array}{l}4.541 \\
(8.0)\end{array}$ & $\begin{array}{l}4.536 \\
(8.0) \\
4.531 \\
(7.9)\end{array}$ & $\begin{array}{l}4.538 \\
(7.9) \\
4.531 \\
(8.0)\end{array}$ & $\begin{array}{l}4.536 \\
(8.0) \\
4.529 \\
(8.0)\end{array}$ & $\begin{array}{l}4.535 \\
4.530 \\
(8.0)\end{array}$ & $\begin{array}{l}4.536 \\
4.530 \\
(7.7)\end{array}$ & $\begin{array}{l}4.549 \\
(7.7)\end{array}$ \\
\hline
\end{tabular}

${ }^{a}$ Chemical shifts are given in ppm, coupling constants (in parentheses) are in $\mathrm{Hz}$.

${ }^{\mathrm{b}}$ Bold numbers correspond to Figs. 5 and 6. 
GlcA-Glc and GlcA-Glc-GlcA, was estimated to be $\sim 2 \%$ each, relative to the total amount of tetrasaccharide as derived from ${ }^{1} \mathrm{H}$ NMR.

Table 2

Molecular masses of the (GlcA-Glc) oligosaccharide fragments $(n=1-7)$, as determined by nano-electrospray mass spectrometry in the negative-ion mode

\begin{tabular}{lll}
\hline$n$ & Calculated & {$[\mathrm{M}-\mathrm{H}]^{-}$} \\
\hline 1 & 356.09 & 355.2 \\
2 & 694.18 & 693.3 \\
3 & 1032.26 & 1031.3 \\
4 & 1370.35 & 1369.4 \\
5 & 1708.43 & 1707.4 \\
6 & 2046.51 & $1022.3[\mathrm{M}-2 \mathrm{H}]^{2-}$ \\
7 & 2384.60 & $1191.5[\mathrm{M}-2 \mathrm{H}]^{2-}$ \\
\hline
\end{tabular}
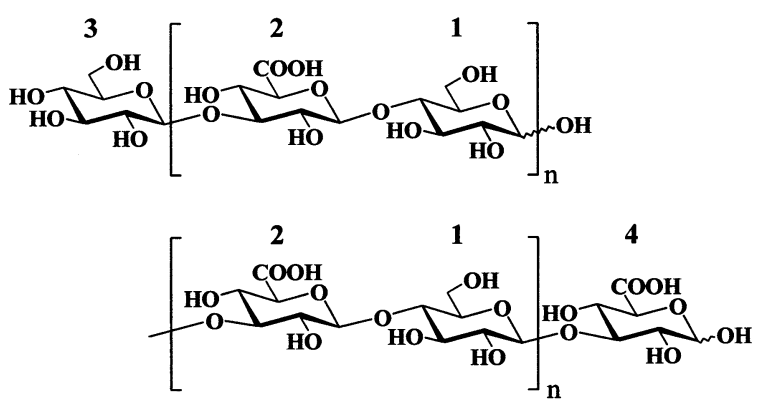

I

Fig. 7. Structures of the possible side products.
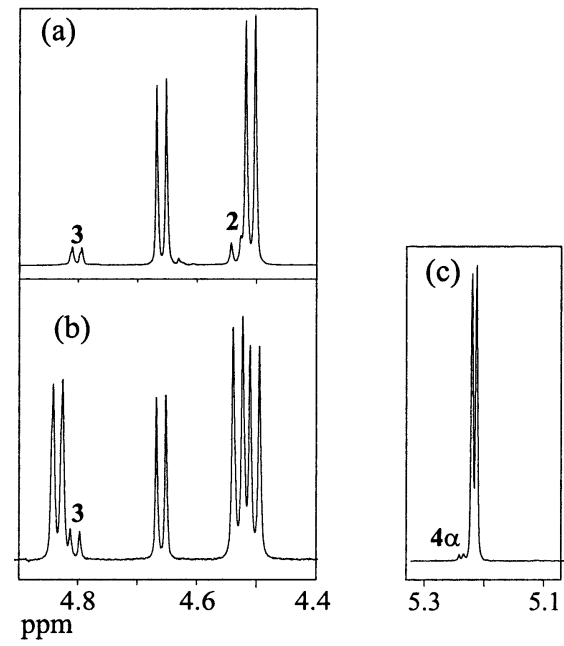

Fig. 8. ${ }^{1} \mathrm{H}$ NMR spectra at $278 \mathrm{~K}$ of the $\beta$-anomeric protons of the fractions of (a) 1 and (b) 2 repeating units containing a side-product; (c) ${ }^{1} \mathrm{H}$ NMR spectrum at $300 \mathrm{~K}$ of the $\alpha$-anomeric protons of the tetrasaccharide fragment. Numbers refer to structures in Fig. 7.

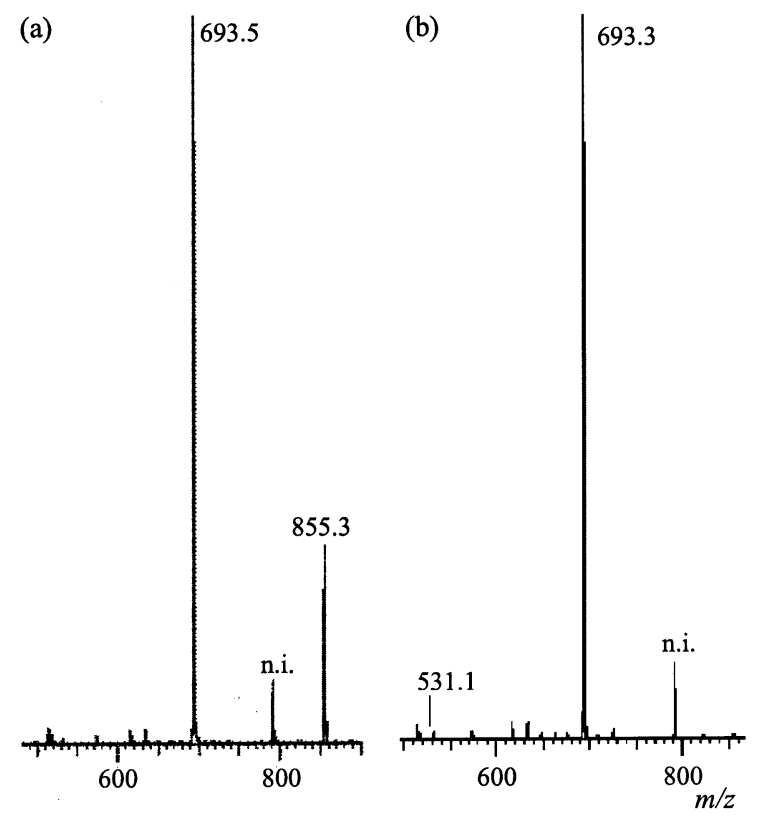

Fig. 9. Nano-electrospray mass spectra of the fractions containing (a) the tetrasaccharide fragment and the side-product and (b) the tetrasaccharide fragment. n.i. = not identified.

\section{Conclusion}

We have reported the isolation of a series of $(\mathrm{GlcA}-$ Glc) ${ }_{n}$ oligosaccharides of increasing degree of oligomerisation $(n=1-7)$ from a partial-acid hydrolysate of the capsular polysaccharide of $S$. pneumoniae type 3 . The purity of the pooled fragments was determined by HPAEC-PAD using an IonPac AS11 column. The structure of the oligosaccharide fragments was assigned by nano-electrospray mass spectrometry and ${ }^{1} \mathrm{H}$ NMR spectroscopy. In earlier studies, partialacid hydrolysis of the capsular polysaccharide of $S$. pneumoniae type 3 was found to lead to a specific cleavage of the $(1 \rightarrow 3)$ linkage. However, the use of modern analytical and physicochemical methods permitted the identification of side-products originating from cleavage of the $\beta$-D-Glc $p \mathrm{~A}-(1 \rightarrow 4)-\beta$-D-Glc $p$ linkage. The oligosaccharides can be used as standards in analytical assays and for the preparation of neoglycoproteins with a defined carbohydrate part, which will facilitate product control. Furthermore, these structures are ideal probes to investigate the immunological effect of the saccharide part in conjugate vaccines, thereby increasing the insight in the immune response at a molecular level.

\section{Acknowledgements}

This work was supported by the European Union program VACNET (grant ERB BIO 4CT960158). 


\section{References}

1. Ellis, R. W.; Granoff, D. M. Development and Clinical Uses of Haemophilus b Conjugate Vaccines; Dekker: New York, 1994.

2. Richmond, P.; Borrow, R.; Miller, E.; Clark, S.; Sadler, F.; Fox, A.; Begg, N.; Morris, R.; Cartwright, K. J. Inf. Dis. 1999, 179, 1569-1572.

3. Rennels, M. B.; Edwards, K. M.; Keyserling, H. L.; Reisinger, K. S.; Hogerman, D. A.; Madore, D. V.; Chang, I.; Paradiso, P. R.; Malinoski, F. J.; Kimura, A. Pediatrics 1998, 101, 604-611.

4. Ravenscroft, N.; Jones, C. Curr. Opin. Drug. Disc. Develop. 2000, 3, 222-231.

5. Costantino, P.; Norelli, F.; Gianozzi, A.; D’Ascenzi, S.; Bartoloni, A.; Kaur, S.; Tang, D.; Seid, R.; Viti, S.; Paffetti, R.; Bigio, M.; Pennatini, C.; Averani, G.; Guarnieri, V.; Gallo, E.; Ravenscroft, N.; Lazzeroni, C.; Rappuoli, R.; Ceccarini, C. Vaccine 1999, 17, 1251-1263.

6. Ravenscroft, N.; Averani, G.; Bartoloni, A.; Berti, S.; Bigio, M.; Carinci, V.; Costantino, P.; D’Ascenzi, S.; Gianozzi, A.; Norelli, F.; Pennatini, C.; Proietti, D.; Ceccarini, C.; Cescutti, P. Vaccine 1999, 17, 2802-2816.

7. Bardotti, A.; Ravenscroft, N.; Ricci, S.; D’Ascenzi, S.; Guarnieri, V.; Averani, G.; Costantino, P. Vaccine 2000, 18, 1982-1993.

8. Kamerling, J. P. In Pneumococcal Polysaccharides: $A$ Chemical View; Thomasz, A., Ed. Streptococcus pneumoniae, Molecular Biology \& Mechanisms of Disease; Mary Ann Liebert: New York, 2000; pp. 81-114.

9. Hotchkiss, R. D.; Goebel, W. F. J. Biol. Chem. 1937, 121, 195-203.
10. Reeves, R. E.; Goebel, W. F. J. Biol. Chem. 1941, 139, 511-519.

11. Mage, R. G.; Kabat, E. A. Biochemistry 1963, 2, $1278-$ 1288.

12. Campbell, J. H.; Pappenheimer, A. M., Jr. Immunochemistry 1966, 3, 195-212.

13. Heidelberger, M.; Kendall, F. E. J. Exp. Med. 1933, 57, 373-379.

14. Becker, G. E.; Pappenheimer, A. M., Jr. Biochim. Biophys. Acta 1966, 121, 343-348.

15. Torriani, A.; Pappenheimer, A. M., Jr. J. Biol. Chem. 1962, 237, 3-13.

16. Dubos, R.; Avery, O. T. J. Exp. Med. 1931, 54, 51-71.

17. Chernyak, A. Ya.; Antonov, K. V.; Kochetkov, N. K. Bioorg. Khim. 1987, 13, 958-966.

18. Chernyak, A. Ya.; Antonov, K. V.; Kochetkov, N. K.; Padyukov, L. N.; Tsvetkova, N. V. Carbohydr. Res. 1985, 141, 199-212.

19. Lefeber, D. J.; Kamerling, J. P.; Vliegenthart, J. F. G. Chem. Eur. J. 2001, 7, 4411-4421.

20. Benaissa-Trouw, B.; Lefeber, D. J.; Kamerling, J. P.; Vliegenthart, J. F. G.; Kraaijeveld, K.; Snippe, H. Infect. Immun. 2001, 69, 4690-4701.

21. Lefeber, D. J.; Aldaba Arévalo, E.; Kamerling, J. P.; Vliegenthart, J. F. G. Can. J. Chem. 2002, 80, 76-81.

22. Laferrière, G. A.; Sood, R. M.; de Muys, J.-M.; Michon, F.; Jennings, H. Vaccine 1997, 15, 179-186.

23. Beuvery, E. C.; van Rossum, F.; Nagel, J. Infect. Immun. 1982, 37, 15-22.

24. Snippe, H.; van Houte, A. J.; van Dam, J. E. G.; de Reuver, M. J.; Jansze, M.; Willers, J. M. N. Infect. Immun. 1983, 40, 856-861.

25. Dubois, M.; Gilles, K. A.; Hamilton, J. K.; Rebers, P. A.; Smith, F. Anal. Chem. 1956, 28, 350-356. 